\title{
Chemical Profile of Essential oil of Ocimum gratissimum L. and Evaluation of Antibacterial and Drug Resistance-modifying Activity by Gaseous Contact Method
}

\author{
Maria Karollyna do Nascimento Silva*, Victória Regina De Alencar Carvalho and Edinardo Fagner Ferreira Matias \\ Faculdade Leão Sampaio-CE-FALS-63180-000, Juazeiro do Norte, CE, Brasil.
}

\begin{abstract}
Introduction: Plant products with antimicrobial potential and ability to modulate the action of drugs have become the target of several studies. Many studies of the species Ocimum gratissimum Lamiaceae have reportedbiological activities in the essential oil and extracts of various parts of the plant. Objective: Evaluate the antibacterial and resistance-modifying activity of the essential oil of $O$. gratissimum (OEOg) and its major compound, Eugenol. Materials and Methods: OEOg was extracted by hydrodistillation and Eugenol was obtained commercially. Multiresistant strains of Escherichia coli and Staphylococos aureus were used to test for drug activity. Antibacterial and resistance-modifying activity of OEOg and Eugenol was evaluated by gaseous contact. Results: Chemical analysis of OEOg demonstrated the presence of Eugenol and other compounds such as 1,8 -cineole and $\beta$-selinene as well. In the evaluation of the antibacterial activity, both OEOg and Eugenol were unable to form a bacterial growth inhibition zone at any of the concentrations tested. However, the modulation tests with amikacin and erythromycin identified synergism with OEOg and eugenol against $E$. coli and S. aureus. Gentamicin combined with OEOg
\end{abstract}

showed antagonism against $S$. aureus but synergism against E.coli. When gentamicin was combined with Eugenol, there was also synergism against $S$. aureus, whereas no effect was seen against E. coli. Conclusion: Given the results obtained in this study, it is concluded that OEOg and Eugenol may eventually represent a new therapeutic tool against antibiotic-resistant bacteria.

Key words: Eugenol, Gaseous contact, Modifying, Ocimum gratissimum, Resistance.

Address for Correspondence:

Maria Karollyna Do Nascimento Silva, Department of Biomedicine, Faculdade Leão Sampaio, FALS-63180-000, Juazeiro do Norte, CE, Brasil.

Phone no: +5588992431586

Email: mariakarollns@hotmail.com

DOI : 10.5530/pj.2016.1.2

\section{INTRODUCTION}

The family Lamiaceae consists of about 240 genera and 7200 species, which can be found in almost all parts of the world. ${ }^{1}$ The genus Ocimum L. consists of more than 150 species, ${ }^{2}$ which are widely used in folk medicine in some countries and are also great sources of essential oils used in industry. ${ }^{3}$

The species Ocimum gratissimum Lamiaceae (O. gratissimum L.) is a subbrush native to Asia and South Africa, but with spontaneous occurrence throughout Brazil. ${ }^{4}$ In the Brazilian Amazon is referred to as "alfavacão" ${ }^{5}$ and is also much used as a spice in cooking. ${ }^{6}$ It iswide spread in traditional medicine in several countries, mainly in the form of teas and infusions of its leaves. ${ }^{7}$ It is used to treat abdominal pain and cough $^{8}$ and colds, pruritus, stress and headache. ${ }^{9}$ Also, there are reports of the use of O. gratissimum to treat upper respiratory tract infections, pneumonia, conjunctivitis and skin diseases. ${ }^{10}$

Various scientific studies have identified some of the plant's activities, such as antidiabetic, ${ }^{11}$ antioxidant, ${ }^{12}$ anxiolytic, ${ }^{13}$ sedative, ${ }^{14}$ antiinflammatory, ${ }^{15}$ hepatoprotective,${ }^{16}$ antitumor, ${ }^{17}$ gastroprotective,${ }^{18}$ and hypolipidemic. ${ }^{19}$ The antibacterial activity of this plant species has been described in many studies that tested various parts of the plant: extract of leaves, ${ }^{20}$ oil from leaves, ${ }^{21}$ extract of leaves and stem, ${ }^{22}$ oil from aerial parts, ${ }^{23}$ and oil from leaves, stem and roots. ${ }^{24}$

Essential oils are compounds found in plants that have different properties related to survival and defense of these plant species. ${ }^{25}$ However, the chemical composition of the oil varies according to the genotype of the plant, geographical origin, environmental conditions, season of the year, method of extraction of this oil and its preservation. ${ }^{26}$

Several chemical shave been found in the essential oil of O. gratissimum (OEOg), such as Eugenol and Thymol, ${ }^{27} \gamma$-muurolene and $\beta$-caryophyllene, ${ }^{28} \alpha$-bisabolene and $\gamma$-terpinene, ${ }^{29} \quad 1.8$-cineole and $\beta$-selinene, ${ }^{30}$ and Geraniol and $p$-cymene. ${ }^{31}$

OEOg is grouped into some chemo types according to the major constituents found, such as Eugenol, Thymol and Geraniol. ${ }^{31}$

Eugenol has a molecular formula of $\mathrm{C}_{10} \mathrm{H}_{12} \mathrm{O}_{2}$, and at normal temperatures, it appears as an oil liquid that is viscous, pale yellow, slightly water soluble and easily dissolved inorganic solvents. ${ }^{32}$ It is widely used as a sedative in dental surgeries, has an antipyretic action, decreases motor activity, has an anticonvulsant effect, is a general anesthetic, and has antibacterial, antiviral and antifungal activities. ${ }^{33}$ It has also been reported to have antioxidant, anti-inflammatory and cytotoxic properties. $^{34}$

Chemicals of natural origin with antimicrobial potential have become targets of study aimed at finding new substances capable of inhibiting the vital process of microorganisms resistant to common drugs. ${ }^{35}$ Antibiotic resistance phenomenon refers to the ability of microorganisms to multiply even at higher drug concentrations. ${ }^{36}$

One type of resistance mechanism developed is the production of enzymes that inactivate the antibiotic. This mechanism is developed by the bacterium Staphylococcus aureus (S.aureus), ${ }^{37}$ a Gram-positive bacterium found on the skin and in the nasal passages of healthy people, which can cause simple infections such as pimples to severe infections such as pneumonia. ${ }^{38}$ Another mechanism is the change in porin channels, which impedes antibiotic uptake by the cell. This type of resistance is commonly developed by Escherichia coli (E.coli) ${ }^{39}$ E. coli is a Gram-negative bacterium commonly found in the intestinal tract of humans, but some serotypes can cause intestinal infections; it is also the most common etiological agent in urinary tract infections. ${ }^{40}$ 
Considering that $O$. gratissimum is widely usedin popular medicine, the investigation of its antibacterial properties and also its combination with other microbial control techniques has become important, since compounds of natural origin may also act as drug resistance modifiers or may potentiate the action of antibiotics against resistant pathogens. ${ }^{41}$

Thus, the aim of this study was to conduct a chemical characterization of the essential oil obtained from O. gratissimum L. leaves and to evaluate OEOg and Eugenol for antibacterial and resistance-modifying activity by the gaseous contact method.

\section{MATERIALS AND METHODS}

\section{Collection of Plant Material}

Leaves of O. gratissimum L. were collected in Chapada do Araripe, Crato municipality, Ceará, Brazil, and avoucher specimen of the species was deposited in the herbarium Dárdano Andrade Lima, University Regional of Cariri, and given the registration number 3978.

\section{Extraction of Essential Oil From Leaves of O. gratissimum L.} OEOg was extracted from fresh leaves of O. gratissimum L. by hydrodistillation using a Clevenger-typeapparatus, where the leaves were crushed and placed in a 5.0-L flask along with $2.5 \mathrm{~L}$ of distilled water, followed by boiling for $2 \mathrm{~h}$. Anhydrous sodiumsulfate $\left(\mathrm{Na}_{2} \mathrm{SO}_{4}\right)$ was added to the essential oil obtained, and this was stored under refrigeration $\left(-4^{\circ} \mathrm{C}\right)$ until time of analysis.

\section{Identification of chemical components}

The chemical analysis of OEOg was performed by gas chromatographycoupled to mass spectrometry (GC/MS) on a Shimadzu instrument. Identification of the components was done by comparison of their mass spectra with standards reported in the literature. ${ }^{42}$

Eugenol was obtained from Sigma Chemical Co. (St. Louis, MO, USA), and the antibiotic disks were from Labor Clin (Brazil). The culture mediawere purchased from HIMEDIA (India), and dimethyl sulfoxide (DMSO) was from Merck (Germany).

\section{Microorganisms}

We used clinical isolates E.coli ${ }^{27}$ and S. aureus 358, multidrug resistant bacterial strains, provided by Institute Oswaldo Cruz. Bothstrains were maintained in Brain Heart Infusion (BHI), and for testing for resistancemodifying activity, the strains were suspended in a test tubewith distilled water to obtain a suspension with turbidity equivalent to 0.5 on the $\mathrm{Mc}$ Farland scale $\left(1 \times 10^{8 \mathrm{CFU}} / \mathrm{mL}\right)$.

\section{Evaluation of Antibacterial Activity}

In Petri dishes containing Mueller-Hinton agar medium, seeding was done to obtain a carpet of bacteria. OEOg and eugenol were diluted in DMSO to obtain solutions containing 50, 25, 12.5 and $6.25 \%$ of these compounds, and $100 \%$ of the substance was also used. An absorbentpaper disk, similar to those used in the antibiogram test, was placed on the lid of each plate, and it was moistened with $10 \mu \mathrm{L}$ of test substance. The plates were incubated in an oven for $24 \mathrm{~h}$ at $37^{\circ} \mathrm{C}$. A millimeter ruler was used to measure the inhibition zones. All tests were performed in triplicate, and only DMSO was used in control plates.

\section{Evaluation of Resistance-modifying activity by gaseous contact}

The evaluation of resistance-modifying activity was performed by the gaseous contact method as modified and reported elsewhere. ${ }^{43}$ In Petri- plates containing Mueller-Hinton agar, seeding was done to obtain a carpet of bacteria. Antibiotic disks with $30 \mathrm{mg}$ amikacin, $10 \mathrm{mg}$ gentamicin and $15 \mathrm{mg}$ erythromycin were placed on the agar. An absorbent paper disk similar to an antibiogram disk was placed on the lid of each plate, and it was moistened with $10 \mu \mathrm{L}$ of the highest concentration of OEOg or Eugenol, where there was growth in the antibacterial activity test, so that through volatilization, the test substance could interact with the antibiotic disks. Other plates containing the drug disks but without oil or Eugenol were also prepared, and afterwards, all plates were incubated for $24 \mathrm{~h}$ at $37^{\circ} \mathrm{C}$. A millimeter ruler was used to measure the inhibition halos of the antibiotics in the presence and absence of the test substances to determine synergism or antagonism. All tests were performed in triplicate, and only DMSO was used in control plates.

\section{Statistical Analysis}

The results were expressed as the arithmetic mean \pm standard deviation, statistically evaluated by analysis of variance (ANOVA) followed by the Bonferroni post-test, utilizing Graph Pad Prism software. Differences were considered significant when $\mathrm{p}<0.05$.

\section{RESULTS AND DISCUSSION}

OEOg obtained by hydrodistillation showed a yield of $0.17 \%$. Other studies have reported yields of OEOg between 0.21 and $0.70 \%{ }^{44-48}$ These differences may be related to changes in environmental factors to whichthe plant is exposed, such as light, temperature and humidity, which significantly affect the emission of volatile compounds and thus the yield and chemical composition. ${ }^{49}$

Through phytochemical oil prospecting, it was possible to identify the presence of a wide variety of chemical compounds (Table 1 and Figure 1).

\begin{tabular}{ccc}
\multicolumn{2}{l}{$\begin{array}{l}\text { Table 1: Chemical composition and percentages of essential oil com- } \\
\text { ponents of Ocimum gratissimum }\end{array}$} \\
\hline Components & R. Time & Composition (\%) \\
\hline 3-Hexen-1-ol & 8.443 & 0.53 \\
1,8-Cineole & 17.956 & 9.69 \\
Cis-Ocimene & 18.168 & 1.49 \\
L-Linalool & 21.909 & 0.42 \\
Linalyl propionate & 27.595 & 0.94 \\
Eugenol & 37.413 & 72.26 \\
$\boldsymbol{\beta}$-Caryophyllene & 40.965 & 3.80 \\
Germacrene-D & 44.915 & 1.73 \\
及-Selinene & 45.314 & 4.25 \\
Bicyclogermacrene & 45.774 & 2.56 \\
Valencene & 46.041 & 1.87 \\
$\boldsymbol{\gamma}$-Muurolene & 46.542 & 0.46 \\
\hline
\end{tabular}

R. Time: Retention Time.

Eugenol is the compound present in greatest quantities in the essential oil obtained from the fresh leaves of O. gratissimum collected around 8:00 h. This compound corresponds to $72.26 \%$ of the substances found, but the percentage of Eugenol in the essential oil can be as high as $98 \%$ at 12:00 h. This compound is responsible for the antimicrobial activity of the plant, so when needed as a local antiseptic, the ideal time to collect the plant is when Eugenol content is highest. Around 17:00 h, Eugenol is only $11 \%$, since the content of this compound in OEOg is affected 


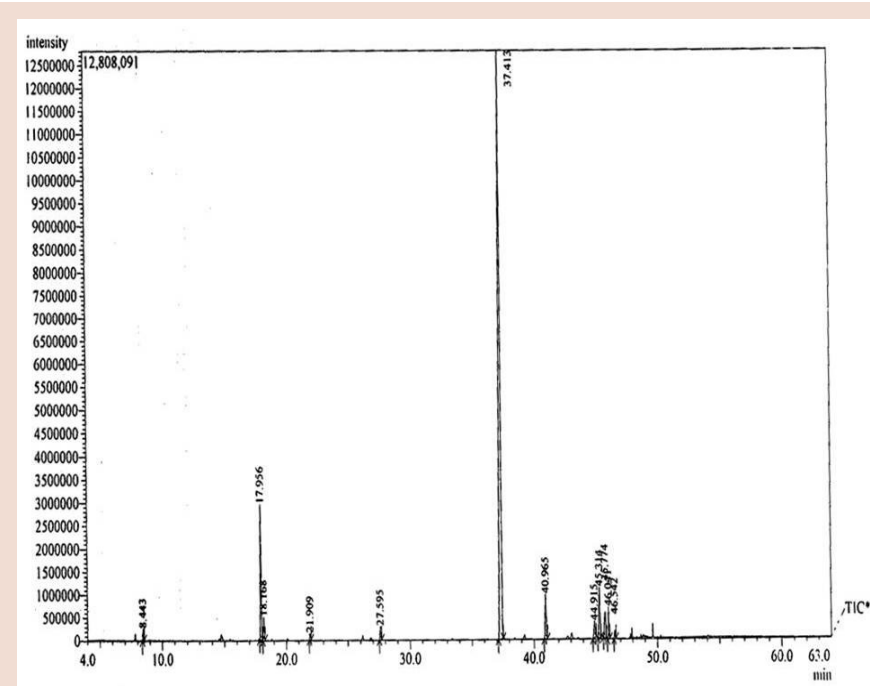

Figure 1: Chromatogram of the Essential Oil from Ocimum gratissimum L. leaves

by sunlight. ${ }^{50}$ During the early morning and late afternoon, there is the predominance of the balsamic principle 1.8-cineol, which explains the popular use of the plant in cold medicine preparations when collected at this time. ${ }^{51}$

Among the chemical constituents of OEOg analyzed, Eugenol was the main component, followed by 1,8-cineol. Other studies also report these compounds as main components of OEOg and classify it as the Eugenol chemotype. ${ }^{52-54}$

In the evaluation of the antibacterial activity by the gaseous contact method, neither OEOg nor eugenol formed a bacterial growth inhibition zone at any of the concentrations tested. In a pilot trial using only DMSO, no antibacterial activity was observed, indicating that there was no toxicity using this solvent. On the basis of these results, we decided to use 100\% OEOg and Eugenol in the resistance-modifying assays.

A study of OEOg evaluating its antibacterial activity against strains of $S$. aureus and $E$. coli by the thin layer chromatography-bioautography method showed inhibition of bacteria growth determined by the formation of inhibition zones around spots corresponding to Eugenol, suggesting that the antibacterial activity of OEOg was due to the action of this compound. ${ }^{29}$ The antibacterial activity of OEOg has also been determined by disk diffusion method, where this compound was effective against Gram-negative and Gram-positive bacteria. ${ }^{21}$ Tests conducted with Eugenol by microdilution technique in broth, also identified antibacterial activity for this compound. ${ }^{55}$ Several studies have reported the antibacterial activity of Eugenol and OEOg. However, in our assays, we did not observe this effect, suggesting that the antibacterial action of these substances is through direct contact with the bacterial cells and not by gaseous contact.

The increasing incidence of bacterial resistance to aminoglycosides is widely recognized as a serious health threat. Thus, natural products of plant origin are increasingly being targeted by studies, and there is evidence that these compounds can alter the effect of antibiotics, either increasing antibiotic activity or reversing resistance. ${ }^{56}$

Aminoglycosides exert their bactericidal effect by binding to the bacterial ribosome. They interact with the cell surface, enter the cell through the cell membrane, and then bind to the $30 \mathrm{~S}$ subunit of the ribosome. Cell death occurs due to drug interference with protein synthesis and misreading of messenger RNA, which leads to changes in membrane function, causing the release of constituents essential for cell viability. ${ }^{57}$

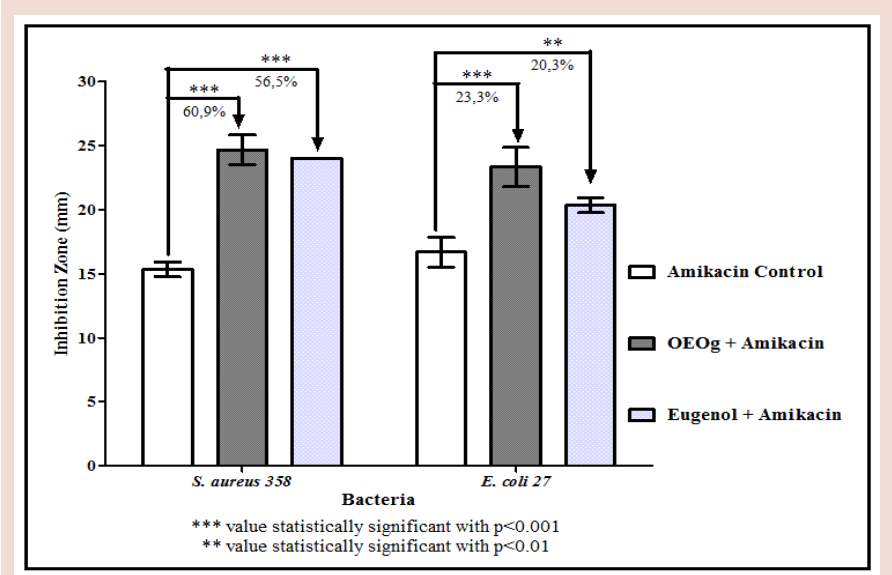

Figure 2: Modulation activity of Aminoglycoside Resistance (Amikacin)

In the drug-modifying assays with amikacin (Figure 2), there was an interaction of OEOg and Eugenol with the antibiotic, resulting in synergism in both $S$. aureus and $E$. coli. That is, when amikacin was combined with the test substances, there was an statistically significant increase in the inhibition halo.

Resistance-modifying assays performed with the microdilution broth method also showed synergism between extracts of $O$. gratissimum and amikacin against $E$. coli and $S$. aureus. ${ }^{58}$ By this same method, a synergistic effect was also observed with the essential oil of Cordia verbenacea DC., when combined with amikacin. ${ }^{59}$

A resistance-modifying effect was observed with erythromycin (Figure 3 ), where there was a synergistic growth inhibitory effect with all combinations tested against the two bacterial strains.

Another study that evaluated the modification of aminoglycosides activity using the gas contact method, reported good results with the essential oil of Lantana montevidens is against multidrug-resistant strains. ${ }^{60}$

Figure 4 shows results for the modulation of gentamicin activity, where antagonism was observed when combined with OEOg against $S$. aureus; that is, there was a decrease in the inhibition halo. However, synergism occurred against E. coli. When gentamicin was combined with Eugenol, there was also synergism against $S$. aureus, but no effect was seen against E. coli, where there was no change in the inhibition halo.

Tests carried out with the isolated compound Carvacrol by the gaseous contact method, also showed a synergistic effect when combined with gentamicin. ${ }^{61}$ The lack of drug modulation observed with $E$. coli can be explained by the fact that Gram-negative bacteria are less sensitive to antibiotics compared to Gram-positive bacteria, ${ }^{62}$ where the former have a highly complex barrier system including an outer membrane consisting of phospholipids, lipopolysaccharídes and proteins, which confers a high degree of impermeability to antimicrobials. ${ }^{63}$ In the present study, E. coli showed less sensitivity to the gentamicin-eugenol combination than did $S$. aureus. Regarding the results in the literature cited and the data obtained in this study, there was divergence as to the effect of OEOg, where the results were better against the Gram-negative strain.

When comparing the drug-modifying effects of Eugenol and OEOg, the results against $E$. coli were better when amikacin and gentamicin were combined with OEOg. Against S. aureus, better results were obtained when gentamicin and erythromycin were combined withEugenol. For other combinations, the test substances did not show differences statistically significanteffects.

Although Eugenol is the major component in OEOg, differences were observed between Eugenol and OEOg in their drug-modifying effect, 


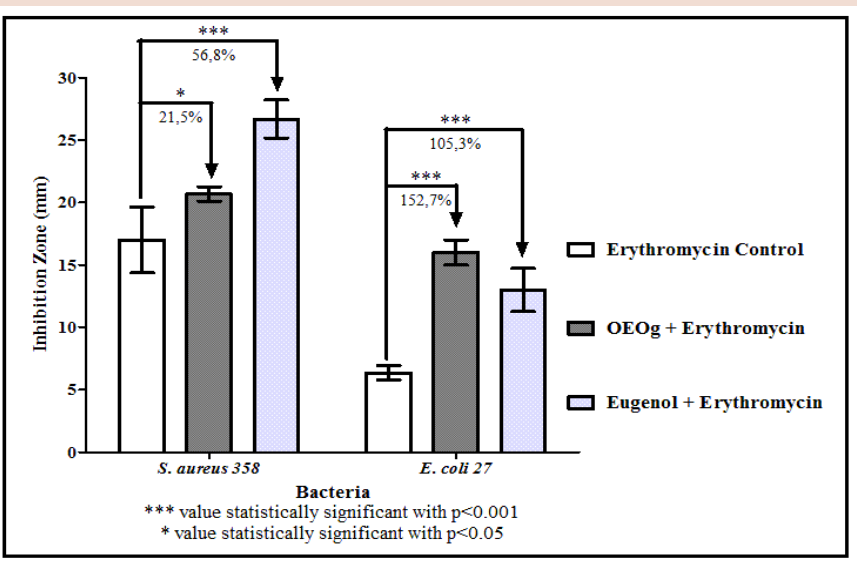

Figure 3: Modulation activity of Aminoglycoside Resistance (Erythromycin)

suggesting that the presence of other substances leads to interactions that influence the effect of the compounds. Many pharmaceutical companies have invested in the study of plantst hat produce pharmacologically active principles, ${ }^{64}$ most research efforts focus on the isolation of active components, but the pharmacological effect of herbal medicines probably involve synergistic actions between the compounds present. ${ }^{65}$

\section{CONCLUSION}

OEOg and Eugenol showed no antibacterial activity when evaluated by the gaseous contact method, but in the resistance-modifying assays, interactions were observed between the test substances and antibiotics, thus demon strating promising results. The combination of natural products of plant origin in the form of complex mixtures or isolated compounds with conventional antibiotics can be an alternative to olin the fight against pathogenic bacteria. Therefore, these products associated with the methodology used in this study can eventually represent a new form of drug therapy against resistant bacteria.

\section{ACKNOWLEDGEMENT}

The authors are thankful for the support and cooperationfrom the college Leão Sampaio FALS-CE, URCA/LPPN/LMBM University Regional do Cariri-CE/Laboratory of Regional Natural Products Research/Laboratory of Microbiology and Molecular Biology.

\section{CONFLICT OF INTEREST}

All authors have not any conflict of interest to disclose.

\section{ABBREVIATION USED}

ANOVA: Analysis of Variance, BHI: Brain Heart Infusion, CFU: Colony Forming Unit, DMSO: Dimethylsulfoxide, GC/MS: Gas Chromatography-Mass Spectrometry, $\mathrm{Na}_{2} \mathrm{SO}_{4}$ : Anhydrous sodium sulfate, $\mathrm{OEOg:} \mathrm{Es-}$ sential Oil of Ocimum gratissimum.

\section{REFERENCES}

1. Harley RM, França F, Santos EP, JS S. Lamiaceae. In: Catálogo de plantas e fungos do Brasil. In: Labaque MC, editor; 2010. p. 1130-46.

2. Mondal S, Mahapatra S, Naik S, Mirdha B. Antimicrobial activities of essential oils obtained from fresh and dried leaves of Ocimum sanctum (L.) against enteric bacteria and yeast. Acta Hort. 2007; 756(2007): 267-70.

3. Khalid KA. Influence of water stress on growth, essential oil, and chemical composition of herbs (Ocimum sp.). Int agrophysics. 2006; 20(4): 289-96.

4. Sartoratto A, Machado ALM, Delarmelina C, Figueira GM, Duarte MCT, Rehder VLG. Composition and antimicrobial activity of essential oils from aromatic plants used in Brazil. Braz J Microbiol. 2004; 35(4): 275-80.

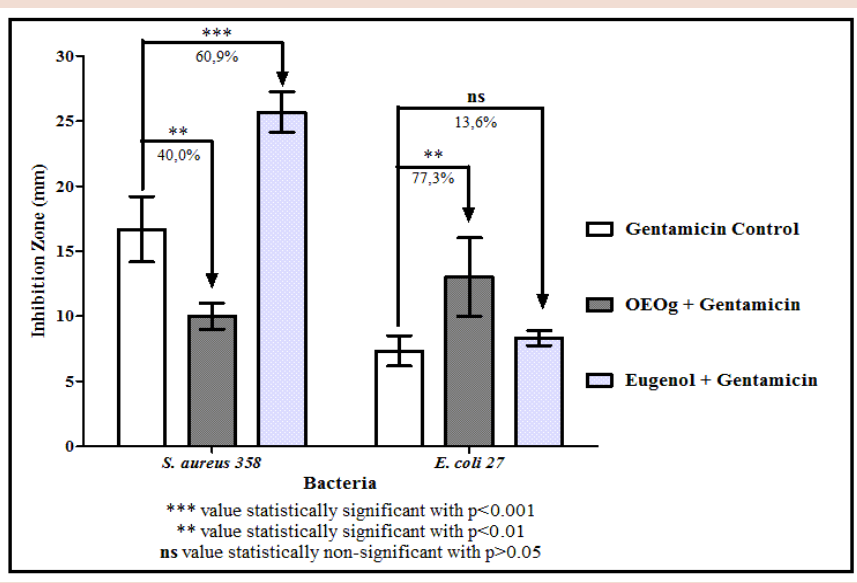

Figure 4: Modulation activity of Aminoglycoside Resistance (Gentamicin)

5. Zoghbi MGB, Oliveira J, Andrade EHA, Trigo JR, Fonseca RCM, Rocha AES. Variation in Volatiles of Ocimum campechianum Mill. and Ocimum gratissimum L. Cultivated in the North of Brazil. Journal Essent Oil Bear Plants 2007; 10(3): 229-40.

6. Lorenzi H, Matos FJA. Plantas medicinais do Brasil: nativas e exóticas. Inst Plant Est. Flora 2008; 2(1): 544.

7. Rabelo M, Souza E, Soares P, Miranda A, Matos F, Criddle D. Antinociceptive properties of the essential oil of Ocimum gratissimum L. (Labiatae) in mice. Braz J Med Biol Res. 2003; 36(4): 521-4.

8. Matasyoh LG, Matasyoh JC, Wachira FN, Kinyua MG, Muigai AWT, Mukiama TK. Chemical composition and antimicrobial activity of the essential oil of Ocimum gratissimum L. growing in Eastern Kenya. Afr J Biotechnol. 2007; 6(6): 760-5.

9. Albuquerque UP, Medeiros PM, Almeida ALS, Monteiro JM, Neto EMdFL, Melo JG, et al. Medicinal plants of the Caatinga (semi-arid) vegetation of NE Brazil: A quantitative approach. J Ethnopharma. 2007; 114(3): 325-54.

10. Adebolu T, Oladimeji SA. Antimicrobial activity of leaf extracts of Ocimum gratissimum on selected diarrhoea causing bacteria in southwestern Nigeria. Afri J Biotec. 2005; 4(7): 682-4.

11. Akpan OU, Bassey RB, Agba BS, Edegha IA. Elevation of serum pancreatic amylase and distortion of pancreatic cyto-architecture in type 1 diabetes mellitus rats treated with Ocimum gratissimum. Niger Med J. 2014; 55(1): 34.

12. Ojo OA, Oloyede O, Tugbobo O, Olarewaju O, Ojo A. Antioxidant and Inhibitory Effect of Scent Leaf (Ocimum gratissimum) on $\mathrm{Fe}^{2+}$ and Sodium Nitroprusside Induced Lipid Peroxidation in Rat Brain In vitro. Adv Bio Res. 2014; 8(1): 08-17.

13. Venuprasad M, Kandikattu HK, Razack S, Khanum F. Phytochemical analysis of Ocimum gratissimum by LC-ESI-MS/MS and its antioxidant and anxiolytic effects. S African J Bot. 2014; 92(1): 151-8.

14. Tankam JM, Ito M. Sedative, anxiolytic and antidepressant-like effects of inhalation of the essential oil of Ocimum gratissimum L. from cameroon in mice. $J$ Pharmacogn Phytochem. 2014; 2(5): 1-9.

15. Okoye FB, Obonga WO, Onyegbule FA, Okechukwu O, Ihekwereme CP. Chemical composition and anti-inflammatory activity of essential oils from the leaves of Ocimum basilicum L. and Ocimum gratissimum L.(Lamiaceae). Int J Pharm Sci Res. 2014; 5(6): 2174-80

16. Awogbindin IO, Tade OG, Metibemu SD, Olorunsogo OO, Farombi EO. Assessment of Flavonoid content, free radical scavenging and hepatoprotective activities of Ocimum gratissimum and Spondias mombin in rats treated with Dimethylnitrosamine. Arch Bas Appl Med. 2014; 2(1): 45-54.

17. Lin CC, Chao PY, Shen CY, Shu JJ, Yen SK, Huang CY, et al. Novel Target Genes Responsive to Apoptotic Activity by Ocimum gratissimum in Human Osteosarcoma Cells. Am J Chin Med. 2014; 42(03): 743-67.

18. Gege-Adebayo GI, Igbokwe VU, Shafe MO, Akintayo CO, Mbaka DI. Anti-ulcer effect of Ocimum gratissimum on indomethacin induced ulcer and percentage of superoxide dismmutase on wistar rats. J Med Med Scien. 2013; 4(1): 8-12.

19. Ekoh SN, Akubugwo El, Ude VC, Edwin N. Anti-hyperglycemic and anti-hyperlipidemic effect of spices (Thymus vulgaris, Murraya koenigii, Ocimum gratissimum and Piper guineense) in alloxan-induced diabetic rats. Int J Biosci. 2014; 4(2): 179-87.

20. Matias EF, Katiucia Santos K, Almeida TS, Costa JG, Coutinho HD. Atividade antibacteriana In vitro de Croton campestris A, Ocimum gratissimum L. e Cordia verbenacea DC. Rev Bras Bioc. 2010; 8(3): 294-8.

21. Matasyoh LG, Matasyoh JC, Wachira FN, Kinyua MG, Muigai AWT, Mukiama TK. Antimicrobial activity of essential oils of Ocimum gratissimum L. from different populations of Kenya. Afr J Tradit Complem Alter Med. 2008; 5(2): 187-93. 
22. Bankole HA, Anjorin AA, Kazeem MI, Ogbeche ME, Agbafor U. Antibacterial activity of Ocimum gratissimum and Gongronema latifolium on Staphylococcus aureus and Salmonella typhi. East Afri J Scienc Tech. 2012; 2(1): 114-28.

23. Kpoviessi BGK, Ladekan EY, Kpoviessi D, Gbaguidi F, Yehouenou B, QuetinLeclerca J, et al. Chemical Variation of Essential Oil Constituents of Ocimum gratissimum L. from Benin, and Impact on Antimicrobial Properties and Toxicity against Artemia salina Leach. Chem Biodiv. 2012; 9(1): 139-50.

24. Adesegun AS, Samuel FO, Anthony OB, Nurudeen OA. Antioxidant and Inhibitory Properties of Essential Oil of Ocimum Gratissimum Against Extracellular Protease of Escherichia coli. losr J Pharmacy. 2013; 3(1): 50-5.

25. SIANI AC, Sampaio A, Souza M, Henriques M, Ramos M. Óleos essenciais: potencial antiinflamatório. Biotecnologia cienc desenvolv. 2000; 16(1): 38-43.

26. Suhr KI, Nielsen PV. Antifungal activity of essential oils evaluated by two differ ent application techniques against rye bread Spoilage fungi. J Appl Microbiol. 2003; 94(4): 665-74.

27. Borges A, Pereira J, Cardoso M, Alves J, Lucena E. Determinação de óleos essenciais de alfavaca (Ocimum gratissimum L.), orégano (Origanum vulgare L.) e tomilho (Thymus vulgaris L.). Rev bras plantas med. 2012; 14(4): 656-65.

28. Silva LL, Heldwein CG, Reetz LG, Hörner R, Mallmann CA, Heinzmann BM. Composição química, atividade antibacteriana in vitro e toxicidade em Artemia salina do óleo essencial das inflorescências de Ocimum gratissimum L., Lamiaceae. Rev bras farmacogn. 2010; 20(5): 700-5.

29. Franco AL. Avaliação da composição química eatividade antibacteriana dos óleos essenciais de Aloysia gratissima (Gillies and Hook) Tronc.(alfazema), Ocimum gratissimum L. (alfavaca-cravo) e Curcuma longa L. (açafrão). Revi Eletr Far. 2007; 4(2): 208-28

30. Benitez NP, León EMM, Stashenko EE. Eugenol and methyl eugenol chemotypes of essential oil of species Ocimum gratissimum L. and Ocimum campechianum Mill. from Colombia. J chromatograc sci. 2009; 47(9): 800-3.

31. Vieira RF, Grayer RJ, Paton A, Simon JE. Genetic diversity of Ocimum gratissimum L. based on volatile oil constituents, flavonoids and RAPD markers. Biochem Syst. Ecol. 2001; 29(3): 287-304.

32. Chaieb K, Hajlaoui H, Zmantar T, Kahla-Nakbi AB, Rouabhia M, Mahdouani $K$, et al. The chemical composition and biological activity of clove essential oil Eugenia caryophyllata (Syzigium aromaticum L. Myrtaceae): a short review. Phytotherapy research: PTR. 2007; 21(6): 501-6.

33. Cheng S-S, Liu J-Y, Chang E-H, Chang S-T. Antifungal activity of cinnamaldehyde and eugenol congeners against wood-rot fungi. Biores techno. 2008; 99(11): 5145-9.

34. Pavithra B. Eugenol-A Review. J Pharm Sci Res. 2014; 6(1): 53-154.

35. Sutcliffe JA. Antibacterial agents: solutions for the evolving problems of resistance. Bioorg med chem lett. 2003; 13(23): 4159-61.

36. Wannmacher L. Uso indiscriminado de antibióticos e resistência microbiana: uma guerra perdida. Uso Racional de Medicamentos: Temas Selecionados Brasília: OPAS/OMS. 2004; 1(4): 1-6.

37. Mingeot-Leclercq MP, Glupczynski Y, Tulkens PM. Aminoglycosides: activity and resistance. Antimicrob Agents Chemother. 1999; 43(4): 727-37.

38. Santos AL, Santos DO, Freitas CC, Ferreira BLA, Afonso IF, Rodrigues CR, et al. Staphylococcus aureus: visiting a strain of clinical importance. J Bras Patol Med Lab. 2007; 43(6): 413-23.

39. Chopra I, Roberts M. Tetracycline antibiotics: mode of action, applications, molecular biology, and epidemiology of bacterial resistance. Microbi Mol Biology Revi. 2001; 65(2): 232-60.

40. Kaper JB, Nataro JP, Mobley HL. Pathogenic Escherichia coli. Nat Rev Microbiol. 2004; 2(2): 123-40

41. Gibbons S. Plants as a source of bacterial resistance modulators and anti-infective agents. Phytoche Rev. 2005; 4(1): 63-78.

42. Adams R. Identification of essential oils components by gas chromatography/ quadrupole mass spectroscopy. Allured Publishing Corporation, Carol. Stream, IL, USA; 2001.

43. Inouye S, Takizawa T, Yamaguchi $\mathrm{H}$. Antibacterial activity of essential oils and their major constituents against respiratory tract pathogens by gaseous contact. J antimic chemothe. 2001; 47(5): 565-73.
44. Dubey NK, Tiwari T, Mandin D, Andriamboavonjy H, Chaumont J-P. Antifungal properties of Ocimum gratissimum essential oil (ethyl cinnamate chemotype). J Fitot. 2000; 71(5): 567-9.

45. Luz JMQ, Ehlert PAD, Innecco R. Horário de colheita e tempo de secagem da alfavaca-cravo. Hortic bras. 2009; 27(1): 539-42.

46. Cortez DAG, Cortez LER, Pessini GL, Doro DL, Nakamura CV. Análise do óleo Essencial da alfavaca Ocimum gratissimum L. Arquivos de Ciências da Saúde da UNIPAR. 1998; 2(2): 125-7.

47. Nakamura CV, Ueda-Nakamura T, Bando E, Melo AFN, Cortez DAG, Dias Filho BP. Antibacterial activity of Ocimum gratissimum L. essential oil. Mem Inst Oswaldo Cruz. 1999; 94(5): 675-8.

48. Silva LL, Heldwein CG, Reetz LG, Hörner R, Mallmann CA, Heinzmann BM. Composição química, atividade antibacteriana in vitro e toxicidade em Artemia salina do óleo essencial das inflorescências de Ocimum gratissimum L, Lamiaceae. Rev bras farmacogn. 2010; 20(5): 700-5.

49. Dudareva N, Pichersky E, Gershenzon J. Biochemistry of plant volatiles. Plant physiology 2004; 135(4): 1893-902.

50. Silva M, Craveiro A, Matos FA, Machado M, Alencar J. Chemical variation during daytime of constituents of the essential oil of Ocimum gratissimum leaves. Rev fitoter. 1999; 70(1): 32-4.

51. Matos F. Plantas medicinais: guia de seleção e emprego de plantas usadas em fitoterapia no Nordeste do Brasil. 2 ed: Fortaleza: imprensa universitária UFC; 2000. p. 346.

52. Ueda-Nakamura T, Mendonça-Filho RR, Morgado-Díaz JA, Maza PK, Dias Filho $\mathrm{BP}$, Cortez DAG, et al. Antileishmanial activity of Eugenol-rich essential oil from Ocimum gratissimum. Parasitol Int. 2006; 55(2): 99-105.

53. Pessoa L, Morais S, Bevilaqua C, Luciano J. Anthelmintic activity of essential oil of Ocimum gratissimum Linn. and eugenol against Haemonchus contortus. Vet Parasit. 2002; 109(1): 59-63

54. Freire CMM, Marques MOM, Costa M. Effects of seasonal variation on the central nervous system activity of Ocimum gratissimum L. essential oil. J ethnopharma. 2006; 105(1): 161-6.

55. Oliveira JG, Abreu Filho BA. Propriedade antimicrobiana do eugenol frente às amostras de Alicyclobacillus spp. isoladas de suco de laranja. Rev Inst Adolfo Lutz. 2012; 71(2): 410-4.

56. Coutinho HD, Costa JG, Lima EO, Falcão-Silva VS, Siqueira-Júnior JP. In vitro interference of Hyptis martiusii Benth. and chlorpromazine against an aminoglycoside-resistant Escherichia coli. The Indian journal of medical research 2009 129(1): 566-8

57. Oliveira JFP, Cipullo JP, Burdmann EA. Nefrotoxicidade dos aminoglicosídeos Rev Bras Cir Cardiovasc. 2006; 21(2): 444-52.

58. Matias EF, Santos FA, Silva J, Souza CE, Tintino SR, Guedes GM, et al. Screening the in vitro modulation of antibiotic activity of the extracts and fractions of Ocimum gratissimum L. Afr J Microbiol Res. 2012; 6(9): 1902-7.

59. Rodrigues FF, Oliveira LG, Rodrigues FF, Saraiva ME, Almeida SC, Cabral ME, et al. Chemical composition, antibacterial and antifungal activities of essential oil from Cordia verbenacea DC leaves. Pharmacognosy Res. 2012; 4(3): 161.

60. Sousa EO, Rodrigues FF, Coutinho HD, Campos AR, Lima SG, Costa JGM. Chemical composition and aminoglycosides synergistic effect of Lantana montevidensis Briq.(Verbenaceae) essential oil. Rec Nat Prod. 2011; 5(1): 60-4.

61. Freitas MA, Andrade JC, Guedes GMM, Tintino SR, Souza CES, Leite NF, et al Avaliação in Vitro da atividade antimicrobiana do carvacrol através dos métodos de contato direto e gasoso. Bioscie J. 2013; 29(3): 781-6.

62. Madigan MT, Martinko JM, Dunlap PV, Clark DP. Microbiologia de Brock. 10th ed. São Paulo: Prentice Hall; 2004. p. 608.

63. Lambert R, Skandamis PN, Coote PJ, Nychas GJ. A study of the minimum inhibitory concentration and mode of action of oregano essential oil, thymol and carvacrol. Journal of applied microbiology 2001; 91(3): 453-62.

64. Rosa DD, Basseto MA, Feliciano F, Neves MB, Baldin EL. Occurrence of Dictyla monotropidia Stål (Hemiptera: Tingidae) on Cordia verbenacea Al. DC in Brazil. Neotrop Entomol. 2008; 37(2): 236-8.

65. Maciel MAM, Pinto AC, Veiga V, Grynberg NF, Echevarria A. Plantas medicinais: a necessidade de estudos multidisciplinares. Quim nova. 2002; 25(3): 429-38. 


\section{PICTORIAL ABSTRACT}

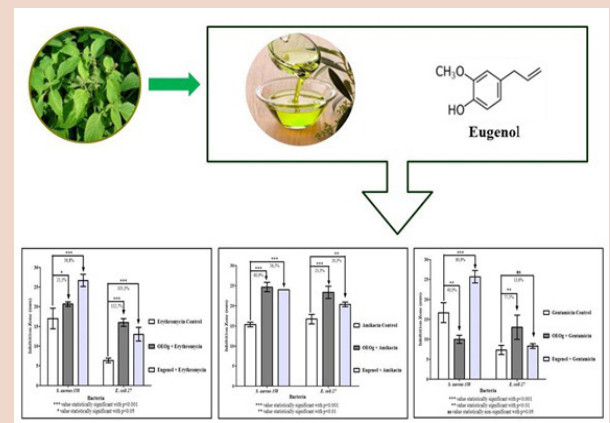

\section{SUMMARY}

- OEOg obtained by hydrodistillation showed a yield of $0.17 \%$ and Eugenol is the compound present in greatest quantities in the essential oil obtained.

- In the evaluation of the antibacterial activity by the gaseous contact method, neither OEOg nor eugenol formed a bacterial growth inhibition zone at any of the concentrations tested.

- In the drug-modifying assays with amikacin, there was an interaction of OEOg and Eugenol with the antibiotic, resulting in synergism.

- Resistance-modifying effect was observed with erythromycin, where there was a synergistic growth inhibitory effect with all combinations tested.

- The modulation of gentamicin activity, where antagonism was observed when combined with OEOg against $S$. aureus. However, synergism occurred against E. coli. When gentamicin was combined with Eugenol, there was also synergism against $S$. aureus, but no effect was seen against $E$. coli.

\section{ABOUT AUTHORS}

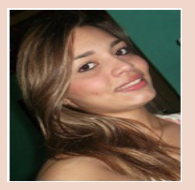

Maria Karollyna do Nascimento Silva: Is graduate in Biomedicine Leão Sampaio College, monitors in the disciplines of Applied Chemistry I and Parasitology Basic. Student at the Scientific Initiation Program (Research Interests: Microbiology and Natural Products). Specialization course in clinical microbiology.

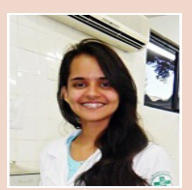

Victória Regina de Alencar Carvalho: Is graduate in Biomedicine Leão Sampaio College, monitors in the discipline of biochemistry. Student at the Scientific Initiation Prog ram (Research Interests: Microbiology and Natural Products). Specialization course in clinical Cytology.

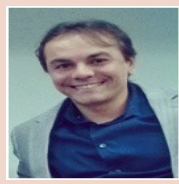

Edinardo Fagner Ferreira Matias: Is graduate in Biology by the University Regional of Cariri-URCA. Specialization in Biology and Chemistry and Master of Science in Molecular Bioprospecting (Line Research Microbiology and Natural Products) by the University Regional of Cariri-URCA. Doctorin Biotechnology (area: Biotechnology Natural Resources) by RENORBIO / UECE. Currently member (researcher) Research Group in Applied Microbiology at the URCA (CNPq). Leader of the Institutional Research Group of the Applied Microbiology Health and Adjunct Profesor at the LeãoSampaio College in Biomedicine courses, nursing, physiotherapy and dentistry. 